\title{
Traumatism in training process of students - volleyball players
}

\author{
Kovalchuk V.Ya. \\ Lutsk National Technical University
}

\begin{abstract}
Purpose:

Material:

Results:

to analyze traumas in training process of students-volleyball players.

42 students participated in the research. Students' medical records were analyzed in the research.

with every year of study in university the quantity of traumas decreased. In 1st year students we found 10 traumas, in 4th year - 5. Ligament sprains are the most frequent kinds of traumas. In total we found 33.3\%. Their main part covers ankle joint traumas. The reasons of them are bursts, stops, changes of movements' direction. Rather frequents (30\%) are maims of knee and elbow joints, caused by falling down. The degree of joints' injury is, as usually, negligible. The highest quantity of moderate and heavy traumas was among $1 \mathrm{st}$ year students ( 9 from 10 ) and 2 nd year students ( 8 from 8 ).

Conclusions: $\quad$ prophylaxis complex for prevention of volleyball traumas has been offered. Volleyball traumas' prevention implies improvement methodic and technique of students-volleyball players' training. The main reasons of traumatism are the following: non observation of sports training principles; poor organizational and logistical support of training process.

Keywords: traumas, volleyball, students, sportsmen, volleyball players.
\end{abstract}

\section{Introduction}

With every year quantity of students, practicing volleyball has been increasing $[1,8,10]$. In this connection requirements to sportsmen's organism have been rising. So, risk of traumas increases $[6,13,17]$. That is why, it is necessary to concentrate the highest attention to prophylaxis and correct treatment sport traumas [10, 14]. Understanding of mechanism of traumas' emersion, as well as their localization permits to realize more effective prophylaxis measures. For this purpose it is necessary to combine the efforts of scientists, coaches, medical workers, dealing with sport traumatism $[2,4,7]$.

The problems of children, youth and sport traumatism were the subject of different authors' studies [1, 3, 5]. It was found that the most frequent were inflammatory and degenerative changes in muscular-skeletal apparatus. They appear as a result of endured and insufficiently cured traumas, repeated micro-traumas and physical overloads $[8,16,20]$. In other works it was noted that children suffer more from traumas than from other diseases [2, 9, 19].

The problems of traumas emersion and prophylaxis were analyzed in different kinds of sports and directions:

- Direct proportion of social -philosophical and spiritual values, person's social orientation and his/ her general culture level with physical health and traumas' presence or absence in sport practicing has been determined [18];

- Influence of tourists' training program for skiing, considering traumatism prophylaxis in conditions of limited time has been shown [27];

- Application of preliminary fatigue principles permits to reduce loads volume and traumatism [25];

- Application of health related technologies in secondary school age girls' football trainings reduces traumatism [26];

- Positive influence of psychological support for recreation sportsmen of game kinds of sports after

(c) Kovalchuk V.Ya., 2017

doi:10.15561/18189172.2017.0105 lower limbs traumas has been shown. The authors notes importance of the mentioned approaches in practicing physical exercises [28];

- Importance of educational programs for rising sportsmen's knowledge about traumatizing at competitions and about first aid measures has been noted [11];

- Possibilities of more effective sportsmen's recreation in different kinds of sports (football, volleyball, run. weight lifting) have been shown [12];

- It is noted that it is necessary to observe safety measures in volleyball training that facilitates reduction of traumatism [24, 29].

That is why in physical education important role is played by complex of prophylaxis measures, directed at prevention from accidents and traumas $[6,13,17]$. It is necessary to build educational-training and sport process in higher educational establishment so that risk of traumas would be completely eliminated.

The purpose of the research is to analyze traumas in training process of students-volleyball players and find the reasons of their emersion, as well as to offer the complex of prophylaxis measures, directed at traumas' prevention.

\section{Material and methods}

Participants: in the research $1^{\text {st }}-4^{\text {th }}$ year students participated (in total - 42 sportsmen).

Organization of the research: for analyzing traumas students' medical records were studied in the research. We analyzed the main reasons of traumatism, traumas' character and heaviness.

Statistical analysis: the results were calculated with the help of SPSS 22 program.

\section{Results}

The following traumas are the most characteristic for volleyball players: upper and lower limbs' maims; ligament strain as well as strain of legs, arms and torso 
muscles; dislocation of shoulder, ankle joints (in less quantity of cases - elbow, wrist and knee elbows); feet blister, muscles' twitching (as a rule shin and hip muscles). Muscles and ligaments' breakages are comparatively rare. As per some data in volleyball players sub-dermal injures of muscles (bursting) are only $0.23 \%$ of all pathologies, ligament breakages (quadriceps muscle of thigh, fingers' extensors, Achilles tendon) - 3.51\% of all pathologies [5, $15,23]$.

\section{Main reasons of traumatism}

Reasons of methodic character: violations of sport training principles (continuity, cycle character, gradualness of loads rising; training in fatigue condition; fulfillment of back-breaking, unfamiliar, difficult exercises; training without arming up; absence of sportsmen's concentration) $[16,22]$.

Reasons of organizational character: coach's qualification; groups' completing without consideration of sex, age and physical fitness; absence of support; fulfillment of exercises "strong against weak" and etc.; excessive quantity of students in sport groups; trainings without coach; training at too cold temperature; sportsmen admittance to trainings without previous medical examination; too early training after disease or traumas; violation of body, arms hygiene; violation of training places maintenance regulations (poor illumination and ventilation; bad quality of site surface; wrong location of inventory and so on); violation of sport discipline and regime; not optimal competition calendar, without considering recreation time of volleyball players' organism, change of climate and hour zones [3, 9, 21].

Considering the absence of data about volleyball players' traumas and injures we fulfilled analysis of characteristic traumas and their quantity in students for the period of their study in universities.

The results of the researches permit to find the character and heaviness of students-volleyball players' traumas and injures. Total quantity of traumas in the years of studying is shown in fig. 1 .

The graph shows that with every training year quantity of students-volleyball-players' traumas reduces. In first year they were ten and by the forth year they reduced twice (5).

The reasons of such results can be quite different. Some students practiced volleyball before entering university. Some students had weal physical and special fitness at the beginning of study in university. As a result there is great quantity of traumas in the $1^{\text {st }}$ year.

Special attention is paid to reasons of traumas' emersion and their prophylaxis. Students' outlook at volleyball traumatism expanded. Besides, as a result of well planned training process, volleyball-players' physical and technical fitness rose. May be just because of these reasons the quantity of forth year students-volleyball

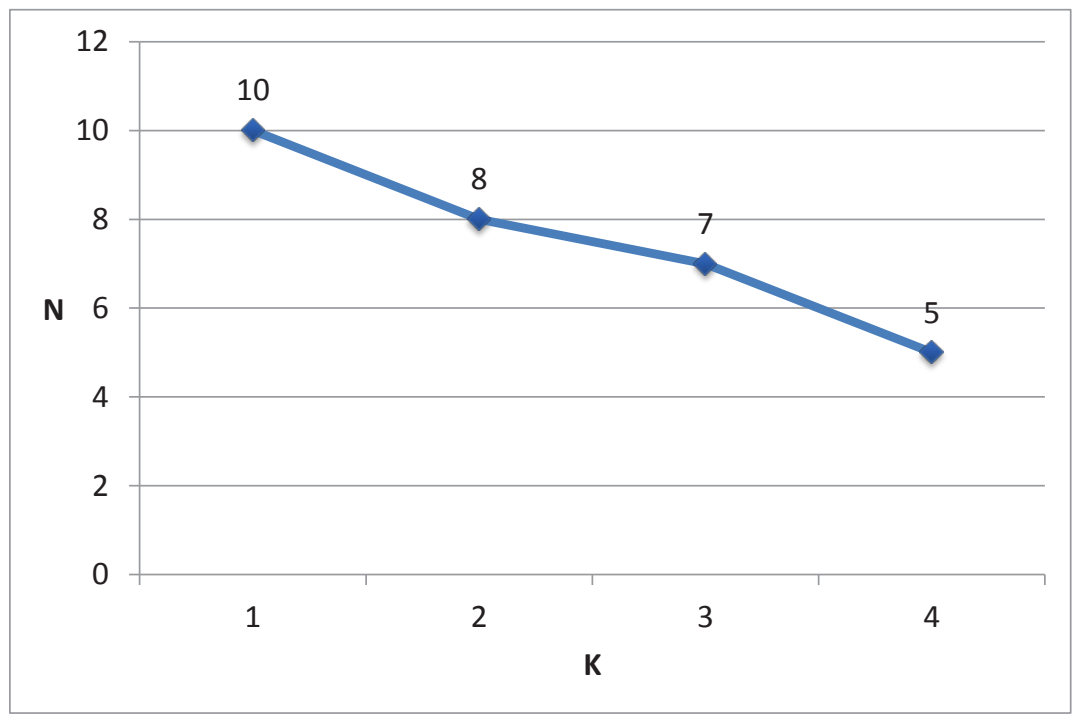

Fig. 1. Dynamic of students-volleyball-players' traumatism for four years of study

Table 1. Characteristic of volleyball players' traumas by the character of damages (quantity)

\begin{tabular}{|c|c|c|c|c|c|}
\hline \multirow{2}{*}{ Traumas } & \multicolumn{4}{|c|}{ Year of study } & \multirow{2}{*}{ Total } \\
\hline & 1 & 2 & 3 & 4 & \\
\hline Maims & 1 & 1 & 5 & 2 & 9 \\
\hline Fractures & 1 & - & - & - & 1 \\
\hline Dislocations & 1 & 1 & - & - & 2 \\
\hline Strains & 3 & 4 & 1 & 2 & 10 \\
\hline Bursts & 3 & 1 & 1 & 1 & 6 \\
\hline Breakages & 1 & 1 & - & - & 2 \\
\hline Total & 10 & 8 & 7 & 5 & 30 \\
\hline
\end{tabular}


players' traumas becomes significantly less (see table 1).

Indicators of traumas and sport damages were reduced to percents (see table 2).

As we can see in table 2 strains are the most frequent in students-volleyball players. In total we found 33.3\%. The main part of them relates to traumas of ankle joint. The reasons of them are bursts, stops, changes of movements' direction as well as poor quality of volleyball players' footwear (see fig. 2).

Maims are rather frequent (30\%): mainly of knee and elbow joints. Such traumas are caused, in general, as a result of falling down. The degree of joint damage is rather negligible with it. The quantity of dislocation is not high and they are localized in wrist joints. The reasons of such traumas are the same as with strains.

Ligaments burst and breakages were 20 and $6.7 \%$ (accordingly) for four years with localization in ankle and knee joints. During four years only one fracture occurred. It is 3.3\% from total quantity of traumas.

Analysis of traumas by the character of damages permitted to determine their heaviness and impact on organism. Results of the research are given in table 3 .

From table 3 we see that the highest quantity of moderate and heavy traumas was in the first year ( 9 from 10) and in the second year (8 from 8). From diagram (see fig. 3) we can see which (by heaviness of impact on organism) prevail in sportsmen.

The diagram shows that $50 \%$ are moderate traumas, $37 \%$ - heavy. The least quantity of traumas is light ones (13\%). So little quantity of light traumas is connected with the fact that they were not paid proper attention and they were not officially registered.

\section{Discussion}

The fulfilled work proves and supplements numerous results $[4,14,19]$ of special literature: the higher level of students' physical and special fitness, the lower percentage of traumas received in training process. Our results prove the data of other studies [7, 20, 23]: solution of volleyball traumas prophylaxis problem implies perfection of technique and training methodic of students-volleyball players.

Table 2. Characteristic of traumas by the character of damage (\%)

\begin{tabular}{ll}
\hline Traumas & Total for $\mathbf{4}$ роки (\%) \\
\hline Maims & 30.0 \\
Fractures & 3.3 \\
Dislocations & 6.7 \\
Strains & 33.3 \\
Bursts & 20.0 \\
Breakages & 6.7 \\
\hline
\end{tabular}

Table 3. Characteristic of traumas by heaviness of their impact on organism (quantity)

\begin{tabular}{lllllll}
\hline Traumas & Year of study & & & & Total & Total in \% \\
\hline Light & $\mathbf{1}$ & $\mathbf{2}$ & $\mathbf{3}$ & $\mathbf{4}$ & 4 & 13 \\
Moderate & 1 & - & 2 & 1 & 15 & 50 \\
Heavy & 5 & 5 & 4 & 1 & 11 & 37 \\
\hline
\end{tabular}

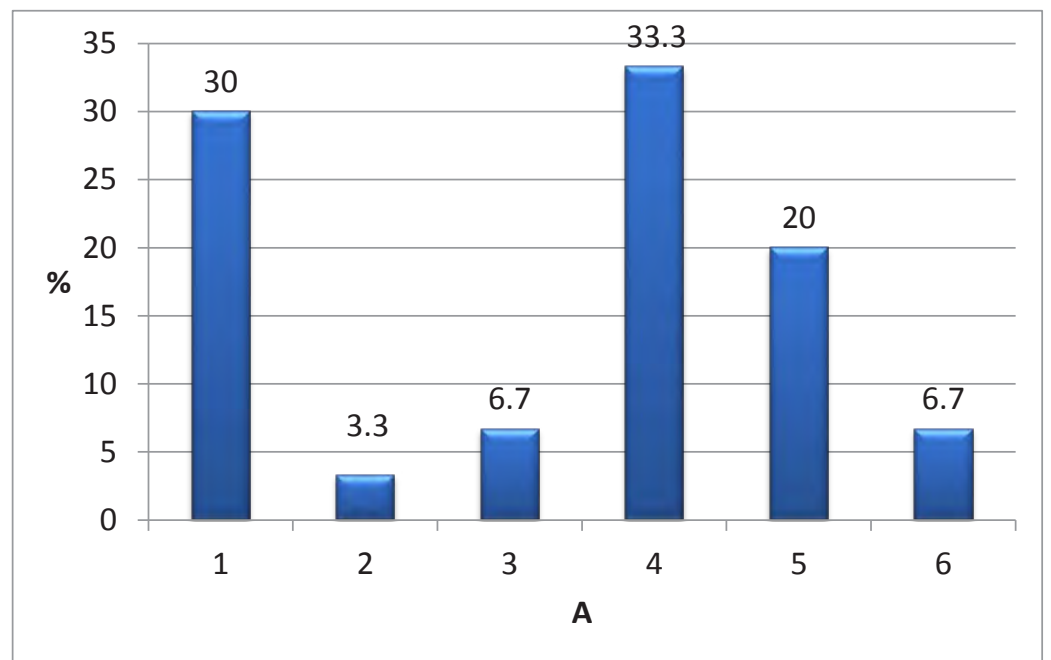

Fig. 2. Characteristic of traumas by the character of damage (\%). A - Kinds of traumas: 1 -maims; 2 -fractures; 3 dislocation; 4 - strains; 5 - bursts; 6 - breakages. 


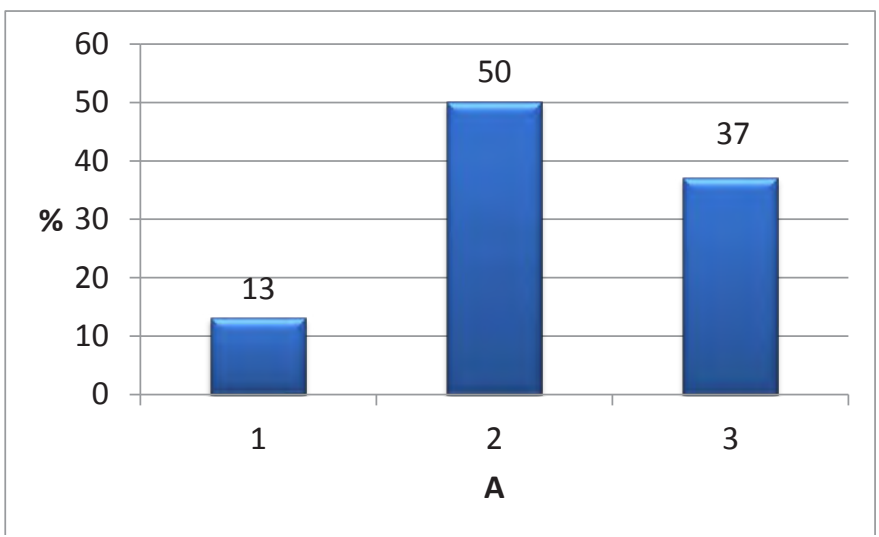

Fig. 3. Characteristic of traumas by heaviness of their impact on organism (\%). A - Kinds of traumas: 1 - light traumas; 2 - moderate traumas; 3 - heavy traumas.

Our results also prove the data of the researches $[15,2122]$ : traumas resulting from physical exercises' practicing are rather frequent; their after effects prevent from physical perfection of person. When determining the frequency and localization of traumas it was found that dislocations, strains, deformations and traumas of joints' and muscles ligaments prevail.

Generalization of our research's results proved [1] existence of clear dependence between physical exercises and sport traumas. We supplemented the following: the first year students-volleyball players will have more traumas and sport injures; with years of students' study the quantity of traumas reduces. It is worth to study prophylaxis of traumatism among students-volleyball

\section{References}

1. Bondar' AI, Shcherba VI, Shutenkova EV. Vnetrenirovochnye faktory podgotovki sportsmenov (na primere volejbola) [Out-of-training factors of sportsmen's training (on example of volleyball)], Minsk: BSATU; 2004. (in Russian)

2. Galinovskij SP. Prichiny travmatizma [Reasons of traumatism], Mogilev: VOOK; 2005. (in Russian)

3. Gamza NA, Ternov GG. Poniatiia i medicinskie terminy $v$ sportivnoj medicine [Concepts and medical terms in sport medicine], Minsk; 2002. (in Russian)

4. Konokh AP. Osobennosti fizicheskoj rabotosposobnosti studentov $\mathrm{V}$ processe ikh obucheniia v vuze [Special aspects of students' physical workability in the process of their study in HEE]. Pedagogics, psychology, medical-biological problems of physical training and sports, 2003;6:93 -100 .

5. Lars Peterson, Per Renstren. Travmy $v$ sporte [Traumas in sports], Moscow: Physical Culture and Sport; 1981. (in Russian)

6. Mardar G, Iachniuk I. Zapobigannia travmatizmu $\mathrm{v}$ procesi pidgotovki sportsmeniv [Prevention from traumatism in the process of sportsmen's training]. Fizichne vikhovannia, sport i kul'tura zdorov'ia u suchasnomu suspil'stvi, 2008;1:82 - 87. (in Ukrainian) players in future researches.

\section{Conclusions}

In our work we proved hypothesis that first year students-volleyball players have more traumas and sport injures and with years of study the traumas' quantity reduces.

The main reasons of traumatism are: violation of sport training principles; level of organizational and logistic support of training process.

\section{Conflict of interests}

The author declares that there is no conflict of interests.

7. Davydov VIu, Kovalenko TG, Kiselev PA, Popova GN. Mery bezopasnosti na urokakh fizicheskoj kul'tury [Safety measures at physical culture lessons], Volgograd: VolSU Publ.; 2003. (in Russian)

8. Murav'ev VA, Sozinova NA. Tekhnika bezopasnosti na urokakh fizkul'tury [Safety measures at physical culture lessons], Moscow: SportAkademPress; 2001. (in Russian)

9. Platonov VN. Sistema podgotovki sportsmenov $v$ olimpijskom sporte [The system of preparation of sportsmen in Olympic sport], Kiev: Olympic Literature; 2004. (in Russian)

10. Trifonov IuN, Kudriashov ON, Kramov IA, Zagrancev VV. Travmatizm pri zaniattiakh fizichnoiu pidgotovkoiu i sportom [Traumatism in physical training and sports practicing], Lviv: VIPC; 1974. (in Ukrainian)

11. Al-Arfaj I, Al-Shammari A, Al-Subai T, Al-Absi G, AlJaffari M, Al-Kadi A. The knowledge, attitude and practices of male sports participants to sportsrelated dental trauma in Khobar and Dammam, Saudi Arabia - A pilot survey. The Saudi Dental Journal, 2016;28(3):136-141.

12. Astur DC, Xerez M, Rozas J, Debieux PV, Franciozi CE, Cohen M. Anterior cruciate ligament and meniscal injuries in sports: incidence, time of practice until injury, and limitations caused after trauma. 
Revista Brasileira de Ortopedia (English Edition) [Internet]. 2016 Jul [cited 2016 Nov 26]; Available from: http://linkinghub.elsevier.com/retrieve/pii/ S2255497116300532

13. Australian Institute of Health \& Welfare - AIHW. Australian's Health. No. 9. Australian Institute of Health \& Welfare. Cat. No. AUS 44. Canbera: Author; 2004.

14. Baar P, Wubbels T. Machiavellianism in Children in Dutch Elementary Schools and Sport Clubs: Prevalence and Stability According to Context, Sport Type, and Gender. The Sport Psychologist. 2011; 25: 444-64.

15. Bryl W, Matuszak K, Hoffman K. Physical activity of children and adolescents with intellectual disabilities - a public health problem. Hygeia Public Health. 2013; 48(1): 1-5.

16. Buckley L, Sheehan M, Chapman R. The inclusion of first aid in an injury prevention curriculum program. In: Cuddihy TF, Brymaer E, editors. Creating Active Futures. Australia; Brisbane: School of Human Movement Studies, Queensland University of Technology; 2009. p. 3-11.

17. Chiodera P, Volta E, Gobbi G, Milioli MA, Mirandola $\mathrm{P}$, Bonetti A, et al. Specifically designed physical exercise programs improve children's motor abilities. Scandinavian Journal of Medicine Science in Sports. 2008; 18: 179-87.

18. Feuerman V.V., Influence of socio-philosophical and spiritual values on the formation of social orientation and physical health specialists the sphere of physical culture and sports. Physical Education of Students, 2014;2:41-45. doi:10.6084/m9.figshare.906859

19. Frandkin AJ, Zazryn TR, Smoliga JM. Effects of warming-up on physical performance: a systematic review with meta-analysis. Journal of Strength and Conditioning Research, 2010; 24(1): 140-148.

20. Guajardo F, Warren B, Wang L. Self-Organizing: From Child's Play to An Effective Wellness Program. International Journal of Kinesiology \& Sports Sciences, 2013; 1(1): 16-22.

21. Haga M. Physical Fitness in Children With high
Motor Competence is different from that in children With Low Motor Competence. Physical Therapy, 2009; 89: 1089-1097.

22. Hootman JM, Dick R, Agel J. Epidemiology of Collegiate Injuries for 15 Sports: Summary and Recommendations for Injury Prevention Initiatives, J Athl Train, 2007;42(2):311 - 319 .

23. Kaufman LB, Schilling DL. Implementation of a strength Training Program for a 5-Year-Old Child with Poor Body Awareness and Development Coordination Disorder. Physical Therapy. 2007; 87(4): 455-467.

24. Shchepotina NY. Model characteristics of competitive activity of different skilled female volleyball players. Pedagogics, psychology, medical-biological problems of physical training and sports, 2015;2:8085. doi: $10.15561 / 18189172.2015 .0214$

25. Slavityak OS. The problem of search safe and effective method in reducing injuries in bodybuilding stage of specialized basic training. Physical Education of Students, 2014;6:63-68. doi:10.15561/20755279.2014.0612

26. Tkachenko SN. Health-technology in the classroom with the girls playing football of secondary school age. Pedagogics, psychology, medical-biological problems of physical training and sports, 2014;11:6165. doi:10.15561/18189172.2014.1111

27. Toporkov AN. The preparation of tourists to the ski sports tours in a limited time in order to prevent injuries and accidents. Physical Education of Students, 2014;4:42-48. doi:10.6084/m9.figshare.979433

28. Zheleznuy OD, Zasik GB, Mukhin VM, Grinchuk OM. Correction of psycho-emotional state of athletes playing sports with the consequences of injuries of the lower extremities. Pedagogics, psychology, medicalbiological problems of physical training and sports, 2014;12:35-39. doi:10.15561/18189172.2014.1207

29. Zhula VP. Development of motive skills of students while making underarm pass during playing volleyball. Physical Education of Students, 2014;6:13-16. doi:10.15561/20755279.2014.0603

Information about the author:

Kovalchuk V.Ya.; http://orcid.org/0000-0002-8835-8781; bakiko_igor@mail.ru; Lutsk National Technical University; Str. Lviv, 75, Lutsk, 43000, Ukraine.

Cite this article as: Kovalchuk VYa. Traumatism in training process of students - volleyball players. Pedagogics, psychology, medical-biological problems of physical training and sports, 2017;1:31-35. doi:10.15561/18189172.2017.0105

The electronic version of this article is the complete one and can be found online at: http://www.sportpedagogy.org.ua/index.php/PPS/issue/archive

This is an Open Access article distributed under the terms of the Creative Commons Attribution License, which permits unrestricted use, distribution, and reproduction in any medium, provided the original work is properly cited (http://creativecommons.org/licenses/by/4.0/deed.en).

Received: 06.12.2016

Accepted: 05.01.2017; Published: 24.01.2017 